\title{
Drip Chemigation of Insecticides in Bell Pepper against Spodoptera litura (Fabricius) under Protected Cultivation
}

\author{
Golla Satish, V. Anitha, T. Uma Maheswari, Bharati N. Bhat ${ }^{1}$, A. Manohar Rao²
}

10.18805/ag.D-5466

\begin{abstract}
Background: Capsicum (Sweet pepper or Bell pepper), Capsicum annuum L. also popularly called as Simla mirch in India is one of the leading vegetables grown in open conditions as well as under protected conditions. It is attacked by various insect and mite pests from seedling to fruiting stage. The damage caused by Spodoptera litura (Fabricius) during flowering and fruit formation is the most concern and farmers everywhere feel the need to protect such high value crops from any type of damage caused by insect pests. Methods: The trial was conducted under poly house condition during kharif 2019 at horticulture garden, College of Agriculture, Rajendranagar, Hyderabad. The experiment was laid out in randomized block design (RBD) with eight treatments replicated thrice in a $7.5 \mathrm{~m} \times 1 \mathrm{~m}$ plot size with a spacing of $45 \mathrm{~cm} \times 40 \mathrm{~cm}$. The capsicum hybrid WS 234 was raised as per the recommended package of practices except plant protection measures. The observations on pest incidence were recorded one day before treatment imposition as pre-treatment count. Post treatment counts were recorded at one, three, five and seven days after each chemigation/spray. Result: The present study indicated that treatment of cyantraniliprole $10.26 \%$ OD @ $90 \mathrm{~g}$ a.i. ha ${ }^{-1}$ applied through drip chemigation was effective by recording minimum larval population with lowest fruit damage over all the other treatments. The next best treatment was cyantraniliprole $10.26 \%$ OD @ $60 \mathrm{~g}$ a.i. ha- ${ }^{-1}$ applied as foliar spray. The order of moderate effective treatments were drip applications

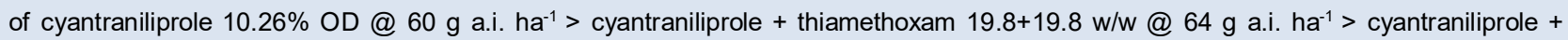
thiamethoxam 19.8+19.8 w/w @ $32 \mathrm{~g}$ a.i. ha ${ }^{-1}>$ imidacloprid 70 WG @ 50 g a.i. ha ${ }^{-1}>$ imidacloprid 70 WG @ 25 g a.i. ha ${ }^{-1}$.
\end{abstract}

Key words: Capsicum, Chemigation, Cyantraniliprole, Spodoptera litura.

\section{INTRODUCTION}

India is a land of diverse agro climatic zones and each of these zones offers a great potential for cultivation of wide range of crops across all seasons. Vegetables form major and important part of our dietary requirements, which are widely grown in rural and peri-urban areas. Capsicum (Sweet pepper or Bell pepper), Capsicum annuum L. also popularly called as Simla mirch in India is one of the leading vegetables grown in open conditions as well as under protected conditions. It is rich in vitamin A (8943 IU), vitamin C (283 $\mathrm{mg}$ ) and minerals like calcium (13.4 mg), magnesium (14.9 $\mathrm{mg}$ ), phosphorous (28.3 $\mathrm{mg}$ ) and potassium $(263.7 \mathrm{mg}$ ) per $100 \mathrm{~g}$ fresh weight (Protected cultivation of Capsicum, IIHR Technical bulletin 2011). Often the productivity of capsicum is very low due to several factors. Among them, insect pests cause severe loss. It is attacked by various insect and mite pests from seedling to fruiting stage. It was reported that a total of 293 insects and mite species attacking the Capsicum crop in the field as well as in storage (Anonymouse, 1987). The damage caused by Spodoptera litura (Fabricius) during flowering and fruit formation is the most concern and farmers everywhere feel the need to protect such high value crops from any type of damage caused by insect pests. They often use synthetic insecticides indiscriminately and insect develop resistance to insecticides is very common in the tropics. Many vegetable growers currently use drip irrigation system for water and nutrient management. The use of such system for specific insecticide applications i.e. drip chemigation would result in an environmentally suitable and
Department of Entomology, Professor Jayashankar Telangana State Agricultural University, Rajendranagar, Hyderabad-500 030, Telangana, India.

${ }^{1}$ Department of Plant Pathlogy, Professor Jayashankar Telangana State Agricultural University, Rajendranagar, Hyderabad-500 030, Telangana, India.

${ }^{2}$ Department of Horiculture, Professor Jayashankar Telangana State Agricultural University, Rajendranagar, Hyderabad-500 030, Telangana, India.

Corresponding Author: Golla Satish, Department of Entomology, Professor Jayashankar Telangana State Agricultural University, Rajendranagar, Hyderabad-500 030, Telangana, India.

Email: satishyadav0.sy@gmail.com

How to cite this article: Golla, S., Anitha, V., Maheswari, T.U., Bhat, B.N. and Rao, A.M. (2022). Drip Chemigation of Insecticides in Bell Pepper against Spodoptera litura (Fabricius) under Protected Cultivation. Agricultural Science Digest. DOI: 10.18805/ag.D-5466.

Submitted: 02-08-2021 Accepted: 07-12-2021 Online: 21-02-2022 cost effective IPM system with less total inputs (time, labour, insecticides) and with less effect on non- target species as compared with multiple foliar sprays of broad spectrum insecticides (Ghidiu et al., 2012). Chemigation' is a term defined as the application of agricultural chemicals, including herbicides, insecticides, fungicides and fertilizers through a center pivot system (Chalfant and Young, 1984) and if it is through drip irrigation system, it is said to be 'drip chemigation' (Wildman and Cone, 1986). Neonicotinoids are 
Drip Chemigation of Insecticides in Bell Pepper against Spodoptera litura (Fabricius) under Protected Cultivation

effective both as contact insecticides and are also taken up by roots from the soil as systemic insecticides which are transported to the foliage contributing to their success.

\section{MATERIALS AND METHODS Experimental layout}

The trial was conducted under poly house condition during kharif 2019 at Horticulture Garden, College of Agriculture, Rajendranagar, Hyderabad. The experiment was laid out in randomized block design (RBD) with eight treatments, i.e. imidacloprid 70 WG @ 25 g a.i ha ${ }^{-1}$ (T1), imidaclorid 70 WG @ $50 \mathrm{~g}$ a.i ha-1 (T2), cyantraniliprole 10.26\% OD @ $60 \mathrm{~g}$ a.i ha $^{-1}$ (T3), cyantraniliprole $10.26 \%$ OD @ $90 \mathrm{~g}_{\text {a.i ha }}{ }^{-1}$ (T4), cyantraniliprole + thiamethoxam 19.8+19.8 w/w @ 32 a.i ha $^{-1}$ (T5), cyantraniliprole + thiamethoxam 19.8+19.8 w/w @ $64 \mathrm{~g}$ (T6), cyantraniliprole 10.26\% OD @ $60 \mathrm{~g}$ (foliar spray) (T7) and control (T8), replicated thrice in a $7.5 \mathrm{~m} \times 1 \mathrm{~m}$ plot size with a spacing of $45 \mathrm{~cm} \times 40 \mathrm{~cm}$. The capsicum hybrid WS 234 was raised as per the recommended package of practices except plant protection measures.

The chemigation system was custom designed to facilitate the experimental design chosen for the study. Treatments were pumped from a 25 litres capacity plastic container, containing insecticide mixed with required quantity of water, using a 1 H.P self-priming pump that pumps the insecticide solution into the pre-determined sub-main as controlled by the valve at the 8 -valve manifold. A single treatment was given by operating each valve at a time that directs the insecticide solution to the selected plots through the drip lines.

The foliar spray treatment was done with a high-volume knapsack sprayer. Both chemigation and foliar spray were executed at the same time.

\section{Observations}

The observations on pest incidence were recorded one day before treatment imposition as pre-treatment count. Post treatment counts were recorded at one, three, five and seven days after each chemigation/spray. Fruit borer (Spodoptera litura) larvae counts were recorded on randomly selected plants in each replication. The percentage reduction of thrips and $S$. litura in all the treatments over control were calculated using modified Abott's formula (Fleming and Ratnakaran, 1985).

\section{Statistical analysis}

The observations recorded were subjected to statistical analysis to know the significance of difference among treatments. Values in numbers were transformed to square root values. The means values of treatments were compared using Duncan's multiple range test (DMRT) as suggested by Gomez and Gomez (1984).

$$
\begin{aligned}
& \text { \% population reduction }= \\
& 1-\left[\begin{array}{cc}
\text { Post treatment population } & \text { Pre treatment population } \\
\text { in treatment } & \text { in control } \\
\hline \begin{array}{c}
\text { Pre treatment population } \\
\text { in treatment }
\end{array} & \frac{\text { Post treatment population }}{\text { in control }}
\end{array}\right] \times 100
\end{aligned}
$$

All the treatments were applied through drip chemigations, except T7 (Cyantraniliprole 10.26\% OD @ $60 \mathrm{~g}$ a.i. ha- ${ }^{-1}$ ) which is applied as foliar spray, simultaneously at the imposition of treatments through drip chemigation.

\section{RESULTS AND DISCUSSION}

The results on the efficacy of different insecticides on Spodoptera litura population at one, three, five and seven days after $1^{\text {st }}$ chemigation applied at 75 days after transplanting (DAT) coinciding with the fruiting stage of capsicum are presented in Table 1. There was no significant difference in larval population at pre count.

At 1 day after treatment (DAT), the insecticidal treatment cyantraniliprole 10\% OD @ 60 g a.i. ha ${ }^{-1}$ (foliar spray) recorded the larval population of $2.06 / 5$ plants/bed and found to be significantly superior compared to other treatments at one day after treatment. The next effective treatments followed were drip applied cyantraniliprole 10\% OD @ $90 \mathrm{~g}$ a.i. ha-1 cyantraniliprole 10\% OD @ $60 \mathrm{~g}$ a.i. ha ${ }^{-1}$, cyantraniliprole + thiamethoxam 19.8+19.8 w/w @64 g a.i. ha $^{-1}$ and $32 \mathrm{~g}$ a.i. ha-1, imidacloprid 70 WG @ $50 \mathrm{~g}$ a.i. ha ${ }^{-1}$ and $25 \mathrm{~g}$ a.i. ha ${ }^{-1}$ with $2.40,2.60,2.72,2.84,3.08$ and 3.20 larvae/5 plants/bed respectively, which were found to be significantly different with each other, whereas untreated control recorded 4.60 larvae/plant.

At 3 DAT, the insecticidal treatment cyantraniliprole $10 \%$ OD @ $90 \mathrm{~g}$ a.i. ha-1(drip applied) recorded the larval population of $1.20 / 5$ plants/bed and was found to be significantly superior compared to other treatments at one day after treatment. Cyantraniliprole 10\% OD @ 60 g a.i. ha $^{-1}$ (foliar spray), the drip applied cyantraniliprole 10\% OD @ $60 \mathrm{~g}$ a.i. ha ${ }^{-1}$, cyantraniliprole + thiamethoxam 19.8+19.8 w/w @ $64 \mathrm{~g}$ a.i. ha ${ }^{-1}$ and $32 \mathrm{~g}$ a.i. ha ${ }^{-1}$, imidacloprid 70 WG @ $50 \mathrm{~g}$ a.i. ha ${ }^{-1}$ and $25 \mathrm{~g}$ a.i. ha-1 with $1.28,1.82,2.02,2.16$, 2.43 and 2.59 larvae/5 plants/bed respectively, which were found to be significantly different with each other, but superior to untreated control with 4.62 larvae/5 plants/bed.

Similar trend was observed at 5 days after treatment, wherein cyantraniliprole 10\% OD @ $90 \mathrm{~g}$ a.i. ha ${ }^{-1}$ proved to be the most effective treatment recording least number of larvae/plant (0.80). The next effective treatments were cyantraniliprole 10\% OD @ $60 \mathrm{~g}$ a.i. ha-1 (foliar spray), cyantraniliprole 10\% OD @ $60 \mathrm{~g}$ a.i. ha ${ }^{-1}$, cyantraniliprole + thiamethoxam 19.8+19.8 w/w @ 64 g a.i. ha ${ }^{-1}$, cyantraniliprole + thiamethoxam @ $32 \mathrm{~g}$ a.i. ha ${ }^{-1}$, imidacloprid 70 WG @ $50 \mathrm{~g}$ a.i. ha ${ }^{-1}$ and imidacloprid 70 WG @ 25 g a.i ha $^{-1}$ with $0.90,1.45,1.68,1.82,2.12$ and 2.30 larvae/5 plants/ bed, which were significantly different from each other, whereas control plot recorded 4.58 larvae/5 plants/bed.

At 7 days after treatment, the trend continued where in cyantraniliprole $10 \%$ OD @ $90 \mathrm{~g}$ a.i. ha ${ }^{-1}$ proved to be the most effective treatment recording least number of larvae/5 plants/bed (0.60). The next effective treatments followed were cyantraniliprole 10\% OD @ 60 g a.i. ha ${ }^{-1}$ (foliar spray), cyantraniliprole 10\% OD @ $60 \mathrm{~g}$ a.i. ha ${ }^{-1}$, cyantraniliprole + thiamethoxam 19.8+19.8 w/w @ 64 g a.i. ha ${ }^{-1}$, 


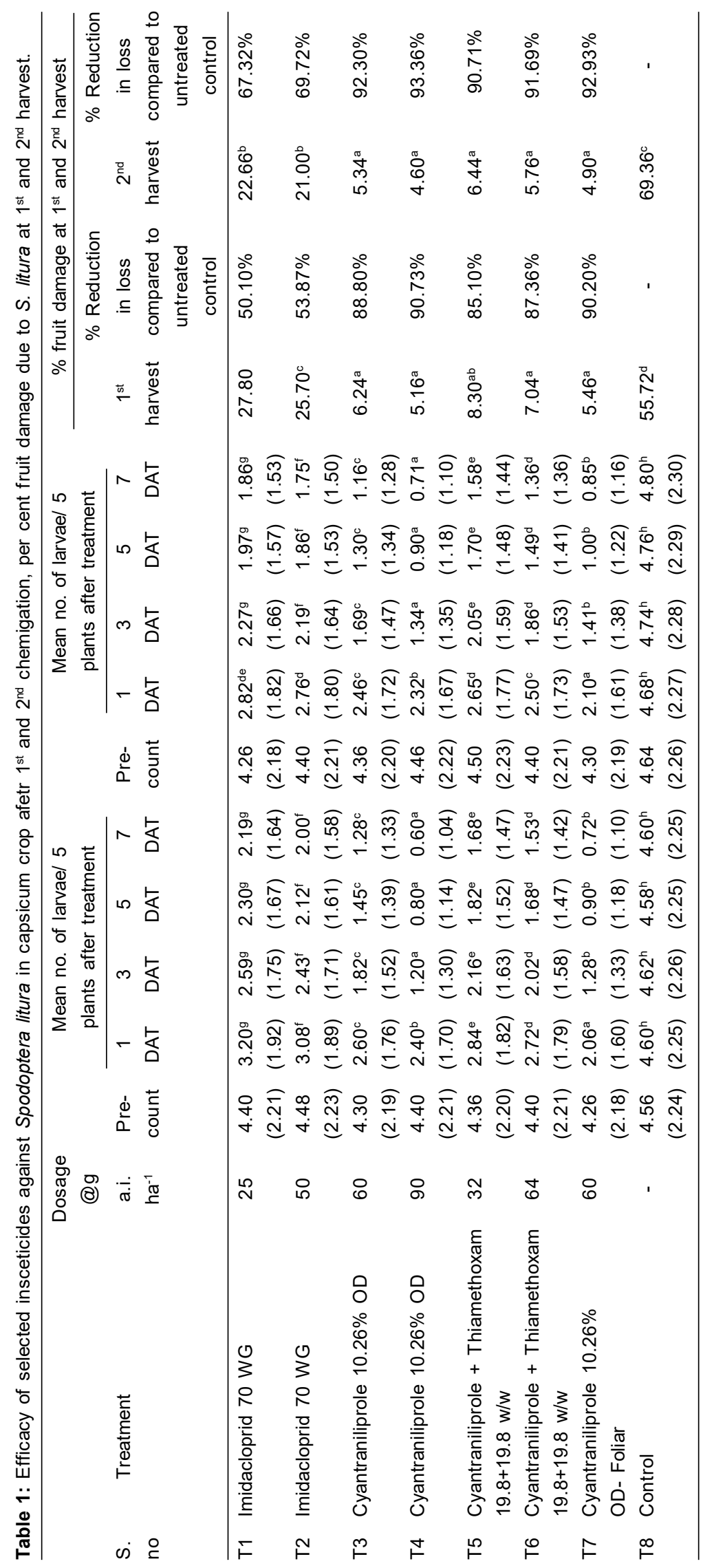


cyantraniliprole + thiamethoxam @ $32 \mathrm{~g}$ a.i. ha ${ }^{-1}$, imidacloprid 70 WG @ 50 g a.i. ha ${ }^{-1}$ and imidacloprid 70 WG @ 25 g a.i ha ${ }^{-1}$ with $0.72,1.28,1.53,1.68,2.00$ and 2.19 larvae/5 plants/ bed, which were significantly different from each other, whereas control plot recorded 4.58 larvae/5 plants/bed.

The $2^{\text {nd }}$ chemigation was taken up at an interval of 20 days after $1^{\text {st }}$ chemigation @ 95 days after transpanting, when the crop is at fruit development to final stage.

At one day after treatment, the insecticidal treatment cyantraniliprole $10 \%$ OD @ $60 \mathrm{~g}$ a.i ha ${ }^{-1}$ (foliar spray) recorded the larval population of 2.10 larvae/5 plants/bed and found to be significantly superior compared to other treatments at one day after treatment. The next effective treatments followed were drip applied cyantraniliprole $10 \%$ OD @ $90 \mathrm{~g}$ a.i. ha ${ }^{-1}$ cyantraniliprole $10 \%$ OD @ $60 \mathrm{~g}$ a.i. ha ${ }^{-1}$, cyantraniliprole + thiamethoxam 19.8+19.8 w/w @64 g a.i. ha $^{-1}$ and $32 \mathrm{~g}$ a.i. ha-1 recording 2.32, 2.46, 2.50 and 2.65 larvae/5 plants/bed respectively, and were significantly different from each other. However, imidacloprid 70 WG @ $50 \mathrm{~g}$ a.i. ha ${ }^{-1}$ and $25 \mathrm{~g}$ a.i. ha ${ }^{-1}$ are less effective, and recorded 2.72 and 2.86 larvae/5 plants/bed respectively, were found to be on par with each other, whereas untreated control recorded 4.68 larvae/5 plants/bed.

At 3 days after treatment, the insecticidal treatment cyantraniliprole 10\% OD @ $90 \mathrm{~g}$ a.i. ha-1 (drip applied) recorded the larval population of $1.34 / 5$ plants/bed and was found to be significantly superior compared to other treatments at one day after treatment. Cyantraniliprole $10 \%$ OD @ $60 \mathrm{~g}$ a.i. ha ${ }^{-1}$ (foliar spray), cyantraniliprole 10\% OD@ $60 \mathrm{~g}$ a.i. ha ${ }^{-1}$, cyantraniliprole + thiamethoxam 19.8+19.8 w/w@64 g a.i. ha ${ }^{-1}$ and $32 \mathrm{~g} \mathrm{a.i.} \mathrm{ha}^{-1}$, imidacloprid 70 WG @ $50 \mathrm{~g}$ a.i. ha ${ }^{-1}$ and $25 \mathrm{~g}$ a.i. ha ${ }^{-1}$ with $1.41,1.69,1.86,2.05,2.19$ and 2.27 larvae/5 plants/bed respectively, which were found to be significantly different with each other, but superior to untreated control with 4.74 larvae/5 plants/bed.

Similar trend was observed at 5 days after treatment, wherein cyantraniliprole $10 \%$ OD @ $90 \mathrm{~g}$ a.i. ha ${ }^{-1}$ proved to be the most effective treatment recording least number of larvae $/ 5$ plants/bed $(0.90)$. The next effective treatments were cyantraniliprole 10\% OD @ $60 \mathrm{~g}$ a.i. ha ${ }^{-1}$ (foliar spray), cyantraniliprole $10 \%$ OD @ $60 \mathrm{~g}$ a.i. ha ${ }^{-1}$, cyantraniliprole + thiamethoxam 19.8+19.8 w/w @ 64 g a.i. ha ${ }^{-1}$, cyantraniliprole + thiamethoxam @ $32 \mathrm{~g}$ a.i. ha ${ }^{-1}$, imidacloprid 70 WG @ 50 g a.i. ha ${ }^{-1}$ and imidacloprid 70 WG @ 25 g a.i ha $^{-1}$ with $1.00,1.30,1.49,1.70,1.86$ and 1.97 larvae/5 plants/ bed, which were significantly different from each other, whereas control plot recorded 4.76 larvae/5 plants/bed.

At 7 days after treatment, the trend continued where in cyantraniliprole $10 \%$ OD @ $90 \mathrm{~g}$ a.i. ha ${ }^{-1}$ proved to be the most effective treatment recording least number of larvae/5 plants/bed (0.71). The next effective treatments followed were cyantraniliprole 10\% OD @ $60 \mathrm{~g}$ a.i. ha-1 (foliar spray), cyantraniliprole 10\% OD @ $60 \mathrm{~g}$ a.i. ha ${ }^{-1}$, cyantraniliprole + thiamethoxam 19.8+19.8 w/w @ 64 g a.i. ha ${ }^{-1}$, cyantraniliprole + thiamethoxam @ $32 \mathrm{~g}$ a.i. ha ${ }^{-1}$, imidacloprid
70 WG @ 50 g a.i. ha ${ }^{-1}$ and imidacloprid 70 WG @ 25 g a.i ha $^{-1}$ with $0.85,1.16,1.36,1.58,1.75$ and 1.86 larvae/5 plants/ bed, which were significantly different from each other, whereas control plot recorded 4.80 larvae/5 plants/bed.

The insecticides in the decreasing order of their efficacy were Cyantraniliprole 10.26\% OD @ $90 \mathrm{~g}$ a.i. ha ${ }^{-1}>$ cyantraniliprole $10.26 \%$ OD @ $60 \mathrm{~g}$ a.i. ha ${ }^{-1}$ (foliar spray)> cyantraniiprole $10.26 \%$ OD @ $60 \mathrm{~g}$ a.i. ha ${ }^{-1}>$ cyantraniliprole + thiamethoxam 19.8+19.8w/w @ 64 g a.i. ha ${ }^{-1}$ >cyantraniliprole + thiamethoxam 19.8+19.8 w/w @ $32 \mathrm{~g}$ a.i. ha-1 > imidacloprid 70 WG @ 50 g a.i. ha ${ }^{-1}>$ imidacloprid 70 WG @ 25 g a.i. ha-1.

The results pertaining to fruit damage due to $S$. litura at $1^{\text {st }}$ harvest ( 85 days after transplanting and 10 days after $1^{\text {st }}$ chemigation) are presented in Table 1 revealed that treatments of cyantraniliprole 10\% OD @ $90 \mathrm{~g}$ a.i. ha ${ }^{-1}$, cyantraniliprole 10\% OD @60 g a.i. ha-1 (foliar spray), lower dose of drip applied cyantraniliprole 10\% OD @ $60 \mathrm{~g}$ a.i. ha $^{-1}$, cyantraniliproe + thiamethoxam 19.8+19.8 w/w @ 64 $\mathrm{g}$ a.i. ha $\mathrm{h}^{-1}$ and $32 \mathrm{~g}$ a.i. ha ${ }^{-1}$ were on par with each other recording per cent fruit damage @ 5.16, 5.46, 6.24, 7.04 and 8.30 respectively. Imidacloprid 70 WG @ $50 \mathrm{~g}$ a.i. ha ${ }^{-1}$ $(25.70 \%)$ and $25 \mathrm{~g}$ a.i. ha ${ }^{-1}(27.80 \%)$ were found to be on par with each other, whereas untreated control recorded $55.72 \%$ fruit infestation, and was significantly differently from other treatments.

The results pertaining to fruit damage due to $S$. litura at $2^{\text {nd }}$ harvest (105 days after transplanting and 15 days after $2^{\text {nd }}$ chemigation) are presented in Table 1 revealed that treatments of cyantraniliprole 10\% OD @ $90 \mathrm{~g}$ a.i. ha ${ }^{-1}$, cyantraniliprole 10\% OD @60 g a.i. ha ${ }^{-1}$ (foliar spray), lower dose of drip applied cyantraniliprole 10\% OD @ $60 \mathrm{~g}$ a.i. ha $^{-1}$, cyantraniiprole + thiamethoxam 19.8+19.8 w/w @ 64 $\mathrm{g}$ a.i. ha $\mathrm{h}^{-1}$ and $32 \mathrm{~g}$ a.i. ha- ${ }^{-1}$ were on par with each other recording per cent fruit damage @ 4.60, 4.90, 5.34, 5.76 and 6.44 respectively. However, imidacloprid 70 WG @ 50 $\mathrm{g}$ a.i. ha ${ }^{-1}$ and $25 \mathrm{~g}$ a.i. ha ${ }^{-1}$, which have recorded the per cent fruit damage @ 21.00\% and $22.66 \%$ respectively were on par with each other, whereas untreated control recorded $69.36 \%$ fruit damage and was significantly different from other treatments.

Since sufficient literature was not available on the efficacy of cyantraniliprole applied via drip chemigation in vegetable crops, the present investigation results were compared with chlorantraniliprole (as both cyantraniliprole and chlorantraniliprole belong to anthranilic diamide class).

The present investigations are in line with Ghidiu et al. (2009) who reported that chlorantraniliprole injected through drip irrigation system at either $0.05 \mathrm{~kg} \mathrm{ha}^{-1}$ or $0.07 \mathrm{~kg} \mathrm{ha}^{-1}$ was more effective in reducing percentage of European corn borer in peppers than standard grower pesticide program of two applications of acephate followed by several applications of indoxacarb. Schuster et al. (2009) reported that drip application of chlorantraniliprole 200 SC @ 5.0 ozl acre minimized the attack of army worm Spodoptera spp., damage in tomatoes. 
In comparison with foliar spray, Patel et al. (2012) reported that cyantraniliprole @ 105 and $90 \mathrm{~g}$ a.i. ha-1 recorded higher per cent larval mortality of Spodoptera litura in cotton than the rest of treatments. Further, Yadav et al. (2012) also reported that cyantraniliprole at the rate of 70 and $80 \mathrm{~g}$ a.i. ha-1 was found to be most effective in reducing the $S$. litura population in table grapes.

\section{REFERENCES}

Anonymous (1987). Literature Survey of Insect Pests of Pepper. ARDC Prog. Report: 77-78.

Chalfant, R.B and Young, J.R. (1984). Management of insect pests of broccoli, cowpeas, spinach, tomatoes, and peanuts with chemigation by insecticides in oils, and reduction of watermelon virus 2 by chemigated oil. Journal of Economic Entomology. 77(5): 1323-1326.

Fleming, R. and Retnakaran, A. (1985). Evaluating single treatment data using Abbott's formula with reference to insecticides. Journal of Economic Entomology. 78(6): 1179-1181.

Ghidiu, G., Kuhar, T., Palumbo, J. and Schuster, D. (2012). Drip chemigation of insecticides as a pest management tool in vegetable production. Journal of Integrated Pest Management. 3(3): E1-E5.
Ghidiu, G.M., Ward, D.L and Rogers, G.S. (2009). Control of European corn borer in bell peppers with chlorantraniliprole applied through a drip irrigation system. International Journal of Vegetable Science. 15(2): 193-201.

Gomez, K.A and Gomez, A.A. (1984). Statistical Procedures for Agricultural Research. Second edition, John Wiley and Sons, New York. 582.

Patel, R.D., Bharpoda, T.M and Borad, P.K. (2012). Larvicidal efficacy of cyantraniliprole against Spodoptera litura (Fabricius) in cotton. An International e-Journal. 1(4): 530533.

Protected Cultivation of Capsicum. (2011). Indian Institute of Horticulture Research. Technical Bulletin No.22 (Revised edition)

Schuster, D.J., Shurtleff, A. and Kalb, S. (2009). Management of armyworms and leafminers on fresh market tomatoes, fall 2007. Arthropod Management Tests. 34(1).

Wildman, T.E. and Cone, W.W. (1986). Drip chemigation of asparagus with disulfoton: Brachycorynella asparagi (Homoptera: Aphididae) control and disulfoton degradation. Journal of Economic Entomology. 79(6): 1617-1620.

Yadav, D.S., Kamte, A.S. and Jadhav, R.S. (2012). Bio-efficacy of cyantraniliprole, a new molecule against Scelodonta strigicollis Motschulsky and Spodoptera litura Fabricius in grapes. Pest Management in Horticultural Ecosystems. 18(2): 128-134. 